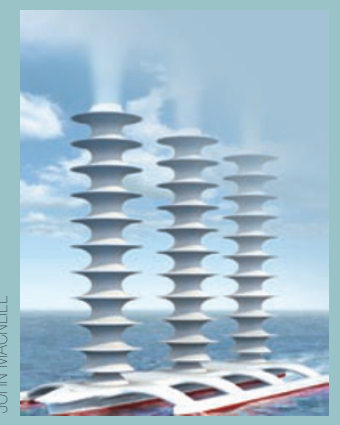

Cover design by Karen Moore

Nature Reports Climate Change

EDITORIAL OFFICE

Editor: Olive Heffernan

Copy Editor: Anna Barnett

Production Editor: Alexandra Hardy

Art Editor: Karen Moore

Web Production Editor: Manpreet Mankoo

MANAGEMENT OFFICE

Managing Director: Steven Inchcoombe

Publishing Director: David Swinbanks

Publisher: Jason Wilde

Associate Publisher: Emma Green

Editor-in-Chief, Nature Publications: Philip Campbell

Marketing Manager: Louise Porter

Managing Production Editor: Donald McDonald

Senior Production Editor: Derna Simpson

Senior Copy Editor: Jane Morris

Advertising Manager, Physical Sciences: Simon Allardice

The Macmillan Building, 4 Crinan St

London N1 9XW, UK

Tel: +44 (0) 2078334000

e-mail: nature@nature.com

VISIT NATURE REPORTS

CLIMATE CHANGE ONLINE

World Wide Web

http://www.nature.com/reports/climatechang

SUBSCRIPTIONS AND CUSTOMER SERVICES

For UK/Europe (excluding Japan):

Nature Publishing Group, Subscriptions, Brunel Road,

Basingstoke, Hants, RG21 6XS, UK.

Tel: +44 (0) 1256329242

Subscriptions and customer services for

Americas - including Canada, Latin America and the

Caribbean: Nature Publishing Group,

Subscription Department, P0 Box 5161, Brentwood,

TN 37024-5161.

Tel: (800) 5242688 (US) or 6158505315

(outside the US). nature REPORTS

the news behind the science, the science behind the news

\section{AN ALTERNATIVE TO THE UN}

Many events alter history, but some are turning points that can put us on a completely different track. The UN conference on climate change in Copenhagen was a defining moment in which we had the opportunity to solve the world's most complex problem. It tested our ability to act collectively for the greater good, and we failed miserably.

Officially, a deal was struck last week in Copenhagen. At the eleventh hour, US President Barack Obama furnished an agreement with leaders from China, India, Brazil and South Africa. Called the Copenhagen Accord, the deal recognizes the need to restrict warming to $2{ }^{\circ} \mathrm{C}$ and outlines financing to help the world's poor cope with climate change, offering US $\$ 30$ billion from rich nations in the period 2010-2012 and US $\$ 100$ billion per year from 2020 . The accord provides guidance on how nations can verify that their emissions are, in fact, falling, and in doing so it irons out a thorny issue that plagued two weeks of talks between almost 200 countries. Importantly, the deal also commits to implementing REDD, the mechanism that will protect forests, keeping their carbon locked up and out of the atmosphere.

But while any deal is better than no deal, the outcome from Copenhagen is worrisome for two reasons. Of most immediate concern, the accord ultimately fails to address the key objective of the UN body that oversees the climate talks - that is, to protect the world from dangerous climate change. Although the accord acknowledges that crossing the $2{ }^{\circ} \mathrm{C}$ threshold would be dangerous, it omits any reference to specific targets for reducing greenhouse gas emissions, not even including the pledges that were - to great applause - put forward by the world's biggest polluters ahead of the summit. Meeting those targets would not guarantee a safe climatic future, but it would at least represent a firm commitment to changing course from business as usual.

Moreover, the outcome of Copenhagen calls into question the competency of the United Nations to solve the climate problem. Despite the presence of delegates from almost 200 countries, an agreement was finally forged behind closed doors between only five; others were then given a choice - they could accept what little was on offer or walk away from two painstaking weeks of talks without a deal and without the financial support they need to cope with the summit's failure.

The manner in which the final deal was struck did not embody democracy, but it did allow for expediency. This suggests that we must now look outside the UN for solutions. With emissions still rising, postponing a decision on a legal treaty by a whole year, until the next UN convention, would be wholly wasteful. The accord that emerged last week signifies a starting point for convergence among the world's biggest polluters, and it renews hope for the speedy passage of legislation through the US Senate. And if the last two weeks have proved anything, it's that when the US moves, others follow.
RESEARCH HIGHLIGHTS

2 Paleoclimate

Past perspective

Alicia Newton

Biodiversity and ecology

Carbon offsets

Olive Heffernan

Ocean science

Consider the lobster

Olive Heffernan

Biodiversity and ecology

Aspen explosion

Alicia Newton

3 Atmospheric science

The long and the short

Olive Heffernan

Cryosphere

Arctic mix-up

Harvey Leifert

\section{FEATURES}

4 Climate science in 2009

Kurt Kleiner

7 Planning for plan B

Mason Inman

\section{COMMENTARY}

\section{Scrap the carbon tariff}

Catherine Izard,

Christopher Weber and

Scott Matthews 